\title{
Synthesis and Structural Analysis of Copper-Zirconium Oxide
}

\author{
Alessandro Figini Albisetti ${ }^{1}$, Carlo Alberto Biffi ${ }^{2, *}$ and Ausonio Tuissi ${ }^{2}$ \\ 1 EDISON S.p.A.-Research and Development Division, Via Foro Buonaparte 31, Milano 20121, Italy; \\ alessandro.figinialbisetti@edison.it \\ 2 CNR-IENI-Institute for Energetic and Interphases, C.so Promessi Sposi 29, Lecco 23900, Italy; \\ tuissi@ieni.cnr.it \\ * Correspondence: carloalberto.biffi@cnr.it; Tel.: +39-0341-499181
}

Academic Editor: Sherif D. El Wakil

Received: 2 March 2016; Accepted: 16 August 2016; Published: 23 August 2016

\begin{abstract}
A new copper-zirconium oxide was synthesized at ambient pressure in air during a thermal treatment. Its crystal structure was analyzed using X-ray Powder Diffraction, and the atomic ratio between copper and zirconium was found performing a Rietveld analysis. An accurate analysis, also comparing this new compound with others present in the literature and which present a similar structure, enables us to characterize the new mixed oxide well. Scanning electron microscopy and thermogravimetric analyses were also performed in order to completely characterize this new material, which is interesting both from an academic point of view for its crystal structure and from an industrial one due to the formation of copper-zirconium-based shape memory alloys during thermal treatment.
\end{abstract}

Keywords: X-ray Powder Diffraction; differential thermal analysis; Rietveld refinement; shape memory alloys

\section{Introduction}

Zirconium dioxide has been extensively studied, and it is still under analysis for its very important and useful chemical and physical properties [1-4]. A large number of attempts were made mixing this oxide with other elements, especially from the transition periods: cerium [5,6], scandium [7], vanadium [8], hafnium [9], etc. Until now, only a few mixed metal oxides containing both zirconium and copper were reported in the literature, though none of them were provided along with a complete structural characterization [10,11] — specifically the cubic and tetragonal phases, which are more interesting from an application point of view and which could have been analyzed by a better method than the monoclinic analysis.

During a thermodiffractometric study of a copper-zirconium alloy [12-15], we observed the formation of an oxide on the surface of the $\mathrm{Cu}_{10} \mathrm{Zr}_{7}$ sample. The experimental conditions in which the oxide was synthesized were the following: starting from room temperature (RT), the temperature was increased in $50 \mathrm{~K}$ steps until $1373 \mathrm{~K}$ (in air). After each step, an X-ray measurement-taken $10 \mathrm{~min}$ from the stabilization of the temperature-was performed. A change in the composition of the sample was observed starting at $923 \mathrm{~K}$. Analyzing the last diffractogram (recorded at $1373 \mathrm{~K}$ ) we noticed that a mixed metal oxide containing copper and zirconium, isomorphous to the crystal structure of monoclinic zirconia, was probably present. Copper(I) oxide was not present, except in a small amount, which we took into account during the structural analysis; however, we could not separate it in the Energy Dispersive Spectroscopy EDS analysis.

We were interested in a thorough characterization of this new monoclinic zirconia phase because of its possible presence in copper-zirconium shape memory alloys (SMAs) after heat treatments. 
Understanding this phase means understanding its contribution to the physical properties of that class of alloys. For this reason, we decided to combine the X-ray data with the data obtained by Scanning Electron Microscopy (SEM) and Thermogravimetry coupled with Differential Thermal Analysis (TG/DTA).

\section{Materials and Methods}

High-purity $\mathrm{Zr}$ and $\mathrm{Cu}$ metals were melted in a vacuum arc furnace with a non-consumable tungsten electrode. The nominal atomic composition of the chosen alloy was $\mathrm{Cu}_{58 \cdot 8} \mathrm{Zr}_{41.2}$ (at \%). The furnace was equipped with a water-cooled copper crucible in order to avoid the contamination of the liquid pool. The material was melted in an inert atmosphere (argon at $400 \mathrm{mbar}$ ) to minimize the oxidation, and the obtained button ingot was re-melted six times, being flipped over after each melting step in order to ensure homogeneity of the chemical composition. The sample was subjected to grinding in an agate mortar in order to produce the powder; later, the powder was heated up to $1100{ }^{\circ} \mathrm{C}(1373 \mathrm{~K})$. The morphology of the powder was analyzed utilizing a LEO 1430 scanning electron microscope (SEM) from Oxford Instruments (Abingdon-on-Thames, UK). In addition, high temperature differential thermal analysis (HTDTA) was also performed using a Q600TA TG-DTA system from TA Instruments (New Castle, DE, USA), on a small sample (about $10 \mathrm{mg}$ ) in a temperature range of $200-1100{ }^{\circ} \mathrm{C}(473-1373 \mathrm{~K})$ at a $20^{\circ} \mathrm{C}(\mathrm{K}) / \mathrm{min}$ heating rate in order to check the oxidation. Diffraction data $(\mathrm{CuK} \alpha, k=1.5418 \AA)$ were collected using a $\theta: \theta$ vertical scan Panalitycal X'Pert PRO diffractometer (Almelo, The Netherlands) equipped with parallel (Soller) slits (0.04 rad) and a RTMS (Real Time Multiple Strip) detector. The generator was operated at $40 \mathrm{kV}$ and $30 \mathrm{~mA}$. Slits used: divergence $0.5^{\circ}$; the scan was performed in the $5^{\circ}-50^{\circ} 2 \theta$ range.

\section{Results and Discussion}

First, the product was observed utilizing X-ray Powder Diffraction (XRD) for microstructural characterization, and SEM for a morphological and compositional characterization. Figure 1 shows the XRD patterns of the initial $\mathrm{Cu}_{10} \mathrm{Zr}_{7}$ phase at room temperature, and of the product obtained after heating up to $1373 \mathrm{~K}$ : it is evident that the heating produces a compound having characteristic peaks, which are the subject of investigation in this work.

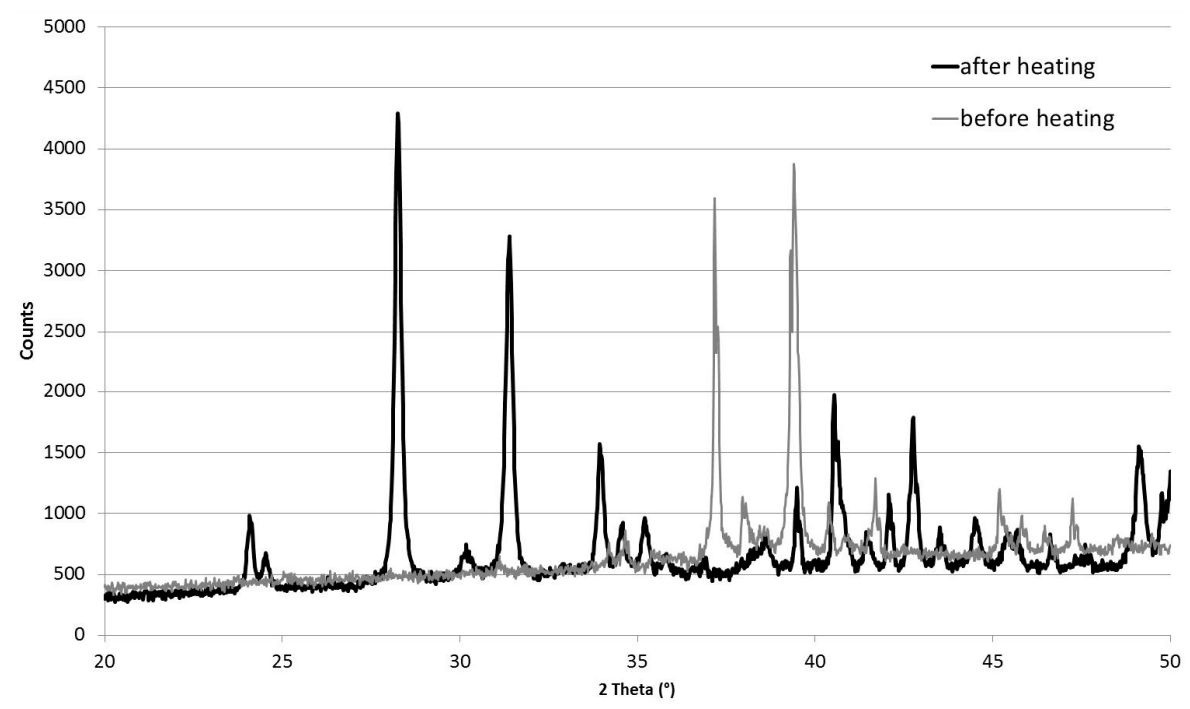

Figure 1. X-ray powder diffraction (XRD) diffractogram of the $\mathrm{Cu}_{10} \mathrm{Zr}_{7}$ sample before and after heating up to $1373 \mathrm{~K}$.

The Secondary Electrons (SE) mode enabled us to observe how the surface of each single grain was attacked by oxygen, forming an almost $10 \mu \mathrm{m}$-thick layer of oxide (estimated from lateral view of 
SEM observation). It is clearly visible how the grain tends to flake, separating the oxide layer from the bulk grain (see Figure 2).

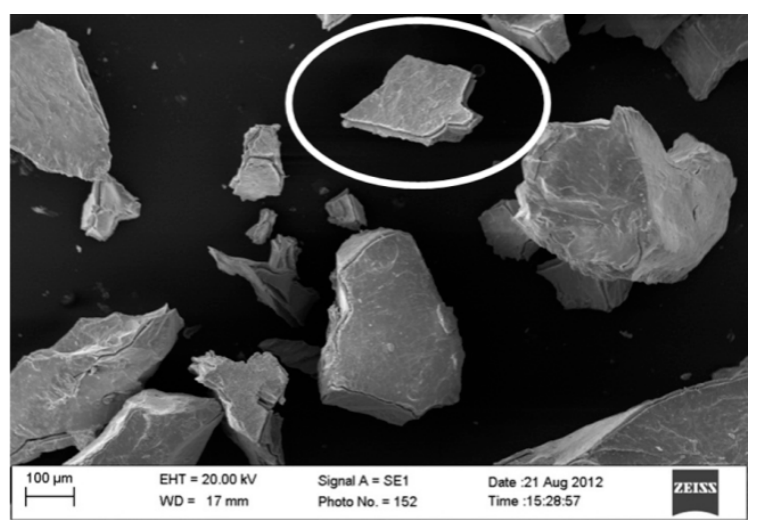

Figure 2. Scanning electron microscopy (SEM) image of powder grains of different size are shown. Each of them present the $\mathrm{Cu}_{10} \mathrm{Zr}_{7}$ compound, showing the characterizing micrometric oxide layer.

On the other hand, the Back-Scattered Electrons (BSE) mode enabled us to determine a sort of confirmation of the $\mathrm{Cu} / \mathrm{Zr}$ ratio: the chemical composition of the oxide was predominantly Zr-based (as expected), because of the higher reactivity of $\mathrm{Zr}$ with $\mathrm{O}$ than $\mathrm{Cu}$. The chemical composition, calculated on the basis of EDS analysis, is the following: $\mathrm{Cu}_{11.6} \mathrm{Zr}_{27.5} \mathrm{O}_{60.9}$ (at \%). For the high reactivity of $\mathrm{Zr}$ with $\mathrm{O}$, TG/DTA analysis was performed on small sample of $\mathrm{Cu}_{10} \mathrm{Zr}_{7}$ intermetallic (about $10 \mathrm{mg}$ in weight) till $1373 \mathrm{~K}$ (the same temperature reached during the $\mathrm{X}$-ray analysis). Figure 3 shows the weight gained, which can be divided into two parts, as a function of the temperature: the first one with a gain rate of about $8.2 \times 10^{-4} \% / \mathrm{K}$ in the temperature range $[473 ; 1023 \mathrm{~K}]$ and the second one of about $4.6 \times 10^{-3} \% / \mathrm{K}$ in the temperature range $[1023 ; 1373 \mathrm{~K}]$.

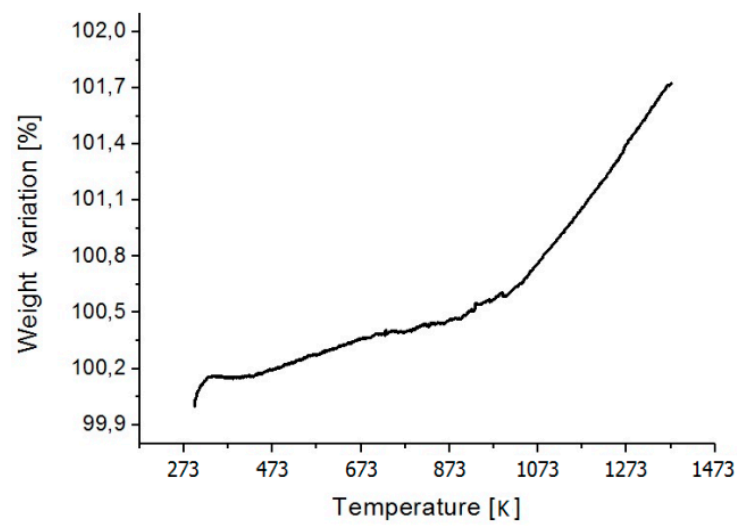

Figure 3. TG/DTA (thermogravimetry coupled with differential thermal analysis) scan of $\mathrm{Cu}_{10} \mathrm{Zr}_{7}$ intermetallic, showing the rate of oxide formation upon heating.

All the XRD diffractograms (recorded during the thermal analysis) were analyzed, and the one recorded at $1373 \mathrm{~K}$ was chosen as the most significant. After a quick qualitative analysis, the presence of some peaks belonging to secondary unknown phases was shown, but their presence can be neglected in order to obtain information on the new oxide found. The sample was cooled to room temperature, and a new diffractogram was recorded in order to confirm the stability of the new compound. Performing a LeBail refinement (where the extra peaks are taken in account but neglected in the real refinement), it was observed that the compound had the same cell and space group of the monoclinic zirconia $\left[\mathrm{P} 2_{1} / c ; a=5.185(1) ; b=5.216(2) ; c=5.375(2) ; \beta=98.86(3)\right] ;$ after, a Rietveld refinement was carried out 
to assess the real copper/zirconium ratio and confirm the crystal structure. Performing the Rietveld refinement (with the TOPAS [16] software), imposing the monoclinic $\mathrm{ZrO}_{2}$ structure without copper substitution, we obtained a high value of agreement coefficient $\left(R_{\mathrm{wp}}=0.287\right)$, which means a bad correlation between the calculated and the real structure. We repeated the refinement substituting a part of $\mathrm{Zr}$ atoms with $\mathrm{Cu}$ atoms. Checking the agreement coefficient $\left(R_{\mathrm{wp}}=0.082\right)$ and analyzing the output data from the refinement, it was possible to determine the $\mathrm{Zr} / \mathrm{Cu}$ ratio (8.09), which means that the mixed-metal oxide has the formula $\mathrm{Cu}_{0.11} \mathrm{Zr}_{0.89} \mathrm{O}_{2}$. The atomic positions and cell parameters were refined, obtaining the output data summarized in Tables 1 and 2. In Table 1, a brief comparison with the crystal structure of the standard $\mathrm{ZrO}_{2}$ is made in order to highlight the differences in cell parameters and density. Figure 4 indicates the agreement between experimental and calculated data after the Rietveld refinement. The copper content measured by EDS is overestimated with respect to the one obtained by XRD. The reason for this disagreement depends on the different penetration depths of the two techniques: X-rays can penetrate only the surface layer, while EDS can also observe the underlying matrix.

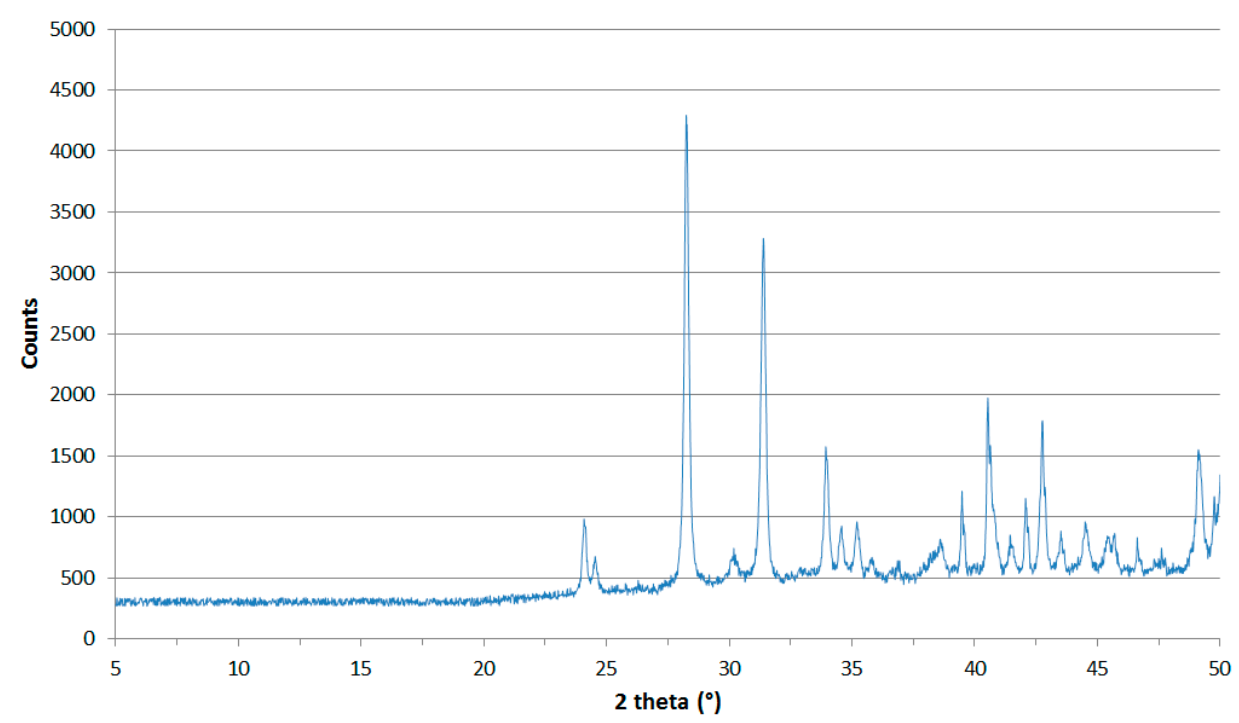

Figure 4. Rietveld refinement, shown in the range $5^{\circ}-50^{\circ} 2 \theta$.

Table 1. Crystal data and data analysis parameters for the $\mathrm{Cu} / \mathrm{Zr}$ oxide and a comparison with the $\mathrm{ZrO}_{2}$ structure (Refinement agreement indices and $2 \theta$ range are the minimum and the maximum values from different certified laboratories).

\begin{tabular}{ccc}
\hline Formula & $\mathrm{Cu}_{\mathbf{0 . 1 1}} \mathbf{Z r}_{\mathbf{0 . 8 9}} \mathbf{O}_{\mathbf{2}}$ & $\mathbf{Z r O}_{\mathbf{2}}[\mathbf{1 7 ]}$ \\
\hline$f w\left(\mathrm{~g} \cdot \mathrm{mol}^{-1}\right)$ & 120.18 & - \\
System & Monoclinic & Monoclinic \\
Space Group & $\mathrm{P} 2_{1} / \mathrm{c}$ & $\mathrm{P} 2_{1} / c$ \\
$a(\AA)$ & $5.1843(6)$ & 5.1460 \\
$b(\AA)$ & $5.2164(9)$ & 5.2116 \\
$c(\AA)$ & $5.3734(9)$ & 5.3130 \\
Mean error & \pm 0.0009 & - \\
$\beta\left(^{\circ}\right)$ & $98.842(4)$ & 99.222 \\
$V\left(\AA^{3}\right)$ & $143.59(2)$ & 143.6 \\
$Z$ & 4 & 4 \\
$d\left(\mathrm{~g} \cdot \mathrm{cm}^{-3}\right)$ & 4.86 & 5.82 \\
$2 \theta$ range $\left(^{\circ}\right)$ & $5-120$ & $7-162$ \\
$R_{\mathrm{p}}$ & 0.061 & $0.031-0.136$ \\
$R_{\mathrm{wp}}$ & 0.082 & $0.039-0.187$ \\
$R_{\mathrm{Bragg}}$ & 4.79 & $2.0-16.1$ \\
\hline
\end{tabular}


Table 2. Fractional atomic coordinates and occupancies.

\begin{tabular}{ccccc}
\hline Atom & $\boldsymbol{X}$ & $\boldsymbol{Y}$ & $\boldsymbol{Z}$ & Occ. \\
\hline $\mathrm{Cu}$ & 0.2899 & 0.0428 & 0.2187 & 0.11 \\
$\mathrm{Zr}$ & 0.2899 & 0.0428 & 0.2187 & 0.89 \\
$\mathrm{O} 1$ & 0.0552 & 0.3123 & 0.3615 & 1 \\
$\mathrm{O} 2$ & 0.4078 & 0.7448 & 0.5408 & 1 \\
\hline
\end{tabular}

\section{Conclusions}

From the Rietveld refinement, a good structural characterization of this new stable mixed metal oxide, $\mathrm{Cu}_{0.11} \mathrm{Zr}_{0.89} \mathrm{O}_{2}$, was performed. It is of particular interest in studying the compositional modification in copper-zirconium alloys during heating treatment. In this work, we perform a thermal analysis starting from $\mathrm{Cu}_{10} \mathrm{Zr}_{7}$, a minor phase present in $\mathrm{CuZr}$ alloys. We are interested in carrying out further investigations on other copper-zirconium phases present in copper-zirconium SMAs, in order to fully characterize that class of compounds. Further work may require the study of the secondary unknown phases in order to evaluate the diffusion process of copper atoms in the ceramic matrix, thus discovering the formation mechanism of the CuZr oxides.

Acknowledgments: The authors thank Giordano Carcano (CNR-IENI Unit of Lecco) for his important contribution in SEM analyses.

Author Contributions: Figini Albisetti A. and Biffi C.A. conceived and designed the experiments; Biffi C.A. prepared the sample and performed the SEM and HTDTA analyses; Figini Albisetti A. performed the X-ray experiment; all the authors analyzed the data and wrote the paper.

Conflicts of Interest: The authors declare no conflict of interest.

\section{References}

1. Steiner, S.A.; Baumann, T.F.; Bayer, B.C.; Blume, R.; Worsley, M.A.; Moberlychan, W.J.; Shaw, E.L.; Schoegl, R.; Hart, A.J.; Hofmann, S.; et al. Nanoscale Zirconia as a Nonmetallic Catalyst for Graphitization of Carbon and Growth of Single- and Multiwall Carbon Nanotubes. J. Am. Chem. Soc. 2009, 131, 12144. [CrossRef] [PubMed]

2. Liu, J.; Meng, X.; Banis, M.N.; Cai, M.; Li, R.; Sun, X. Crystallinity-Controlled Synthesis of Zirconium Oxide Thin Films on Nitrogen-Doped Carbon Nanotubes by Atomic Layer Deposition. J. Phys. Chem. 2012, C116, 14656. [CrossRef]

3. Piticescu, R.M.; Piticescu, R.R.; Taloi, D.; Badilita, V. Hydrothermal synthesis of ceramic nanomaterials for functional applications. Nanotechnology 2003, 14, 312. [CrossRef]

4. Chen, Y.Y.; Wei, W.J. Processing and characterization of ultra-thin yttria-stabilized zirconia (YSZ) electrolytic films for SOFC. Solid State Ionics 2006, 177, 351. [CrossRef]

5. Varez, A.; Garcia-Gonzalez, E.; Jolly, J.; Sanz, J. Structural characterization of $\mathrm{Ce}_{1-x} \mathrm{Zr}_{x} \mathrm{O}_{2}(0 \leq x \leq 1)$ samples prepared at $1650^{\circ} \mathrm{C}$ by solid state reaction: A combined TEM and XRD study. J. Eur. Ceram. Soc. 2007, 27, 3677. [CrossRef]

6. Yashima, M.; Hirose, T.; Katano, S.; Suzuki, Y. Structural changes of $\mathrm{ZrO}_{2}-\mathrm{CeO}_{2}$ solid solutions around the monoclinic-tetragonal phase boundary. Phys. Rev. B Condens. Matter Mater. Phys. 1995, 51, 8018. [CrossRef]

7. Fujimori, H.; Yashima, M.; Kakihana, M.; Yoshimura, M. Structural Changes of Scandia-Doped Zirconia Solid Solutions: Rietveld Analysis and Raman Scattering. J. Am. Ceram. Soc. 1998, 81, 2885. [CrossRef]

8. Torres, F.J.; Amigo, J.M.; Alarcon, J. X-ray powder diffraction study of monoclinic $\mathrm{V}^{4+}-\mathrm{ZrO}_{2}$ solid solutions obtained from gels. J. Solid State Chem. 2003, 173, 40. [CrossRef]

9. Yashima, M.; Tsunekawa, S. Structures and the oxygen deficiency of tetragonal and monoclinic zirconium oxide nanoparticles. Acta Crystallogr. Sect. B Struct. Sci. 2006, 62, 161. [CrossRef] [PubMed]

10. Bhagwat, M.; Ramaswamy, A.V.; Tyagi, A.K.; Ramaswamy, V. Rietveld Refinement Study of Nanocrystalline Copper Doped Zirconia. Mater. Res. Bull. 2003, 38, 1713. [CrossRef]

11. Liang, $\mathrm{Q} . ; \mathrm{Wu}, \mathrm{X}$.; Weng, D.; $\mathrm{Lu}, \mathrm{Z}$. Selective oxidation of soot over $\mathrm{Cu}$ doped ceria/ceria-zirconia catalysts. Catal. Commun. 2008, 9, 202. [CrossRef] 
12. Albisetti, A.F.; Biffi, C.A.; Tuissi, A. Synthesis and structural analysis of $\mathrm{Cu}_{10} \mathrm{Zr}_{7}$. J. Alloy. Compd. 2012, 544, 42. [CrossRef]

13. Biffi, C.A.; Figini, A.; Tuissi, A. Influence of compositional ratio on microstructure and martensitic transformation of CuZr shape memory alloys. Intermetallic 2014, 46C, 4. [CrossRef]

14. Biffi, C.A.; Albisetti, A.F.; Tuissi, A. CuZr based shape memory alloys: Effect of $\mathrm{Cr}$ and Co on the martensitic transformation. Mater. Sci. Forum 2013, 738-739, 167-171. [CrossRef]

15. Biffi, C.A.; Coduri, M.; Yoshida, H.; Soejima, Y.; Nishida, M.; Tuissi, A. The effect of thermal cycling on the martensitic transformation in equiatomic CuZr shape memory alloy. J. Alloy. Compd. 2015, 653, 591. [CrossRef]

16. Topas Academic v.4.0 Software Provided by Alan Coehlo. Available online: http://www.topas-academic.net (accessed on 17 August 2016).

17. Hill, R.J.; Cranswick, L.M.D. International Union of Crystallography. Commission on Powder Diffraction. Rietveld refinement round robin. II. Analysis of monoclinic $\mathrm{ZrO}_{2}$. J. Appl. Cryst. 1994, 27, 802. [CrossRef]

(C) 2016 by the authors; licensee MDPI, Basel, Switzerland. This article is an open access article distributed under the terms and conditions of the Creative Commons Attribution (CC-BY) license (http://creativecommons.org/licenses/by/4.0/). 